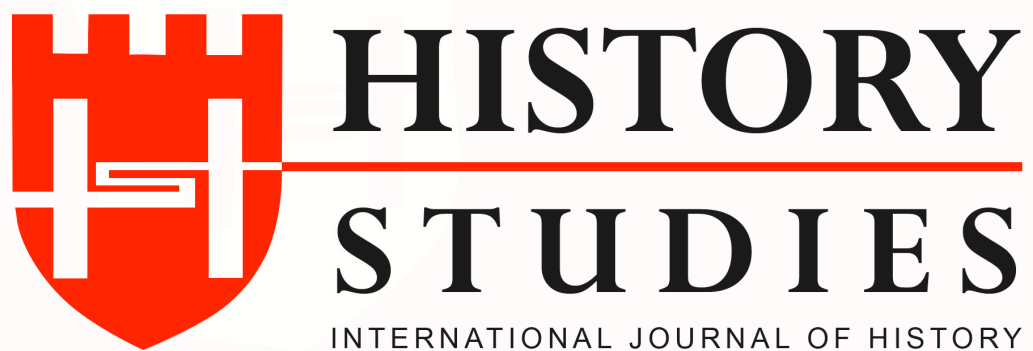

\author{
ISSN: 13094173 (Online) 1309 - 4688 (Print) \\ Volume 11 Issue 5, October 2019 \\ DOI Number: 10.9737/hist.2019.774 \\ Araştırma Makalesi
}

Makalenin Geliş Tarihi: 18.06.2019 Kabul Tarihi: 02.10.2019

Atıf Künyesi: Fatma Çapan, “İmparator Theophilos Döneminde (829-842) Doğu Roma İmparatorluğu ile İslam Dünyası Arasındaki İlişkiler", History Studies, 11/5, Ekim 2019, s. 1491-1508.

\title{
İmparator Theophilos Döneminde(829-842) Doğu Roma İmparatorluğu ile İslam Dünyası Arasındaki İlişkiler
}

\author{
The Relationship Between The Eastern Roman Empire and The Islamic World in The \\ Period of The Empire Theophilos (829-842)
}

\section{Dr. Fatma Çapan}

ORCID No: 0000000286824179

Gaziantep Üniversitesi

\section{Özet}

Doğu Roma İmparatorluğu tarihsel süreç içerisinde ülkesinin doğu sınırlarında çeşitli kavimlerin tehditi altında kalmıştır. Bunlardan en önemlilerinden biri de Suriye'nin kuzeyinden Anadolu içlerine hatta İstanbul'a kadar uzanan Arap-İslam dünyasından gelen tehditler olmuştur. Hz. Muhammed(S.A.V)'in İslam dinini tebliğ etmesiyle başlayan bu süreç Dört Halife dönemi, Emeviler ve Abbasiler döneminde yoğun bir şekilde devam etmiştir. Doğu Roma İmparatorluğu zaman zaman İslam dünyasına karşı uzun süren zorlu savaşlar yapmış, hatta başkent İstanbul dahi Araplar tarafından birkaç kez kuşatılmıştır. Ancak tüm bunların yanı sıra Doğu Roma İmparatorluğu, İslam dünyasından sosyo-kültürel anlamda da etkilenmiştir. İmparator Theofilos dönemi bu etkileşimin açık bir şekilde gözler önüne serildiği bir dönem olmuştur. İmparator Theofilos, Abbasi halifeleri Me'mun ve Mutasım ile ülkesini korumak için birçok savaşın yanı sıra siyasi-diplomatik manevralara başvurmuştur. Bu noktada İslam dünyasındaki iç karışıklıklardan yararlanmak için her iki halife döneminde de Babek El Harami isyanını desteklemiştir. Diğer yandan Endülüs Emevi Emiri II. Abdurrahman'a elçilik heyeti göndererek onları Abbasilere karşı kışkırtmaya çalışmıştır. Ancak İmparator bir yandan İslam dünyasına karşı bu tür mücadele tedbirleri alırken diğer yandan ise İslam dünyasına karşı hayranlığını gizleyememiştir. Abbasi halifelerinin saraylarına benzer kendine bir saray yaptırması, tasvir kırıcılık politikaları izlemesi, Abbasi Halifesi Harun Reşid gibi tebdili kıyafet ile halkının arasında dolaşması bunun en açık örneklerindendir. Bu nedenle İmparator Theofilos, İslam dünyasına hayranlığı ile tanınan bir imparator olarak tarihi kayıtlara geçmiştir.

Anahtar Kelimeler: Doğu Roma İmparatorluğu, Theofilos, İslam Dünyası, Abbasi, Endülüs.

\section{Abstract}

The Eastern Roman Empire was historically threatened by various tribes on the eastern borders of the country. One of the most important of these was the threats coming from the Arab-Islamic world, extending from the north of Syria to the inner Anatolia and even to Istanbul. Hz. Muhammad (S.A.V) the process of Islam, the Four Caliphs, the Umayyad and Abbasid period continued intensively. From time to time, the Eastern Roman Empire fought long wars against the Islamic world, and even the capital, Istanbul, was besieged by the Arabs several times. However, in addition to these, the Eastern Roman Empire was also affected socio-culturally by the Islamic world. The period of Emperor Theophilos was a period in which this interaction was clearly revealed. Emperor Theophilos, with the Abbasid caliphs Ammun and Mutasim, resorted to political-diplomatic maneuvers as well as many 
wars to protect his country. At this point, in order to take advantage of the internal turmoil in the Islamic world, Babek al Harami supported the rebellion during both caliphs. On the other hand, the Umayyad Emir of Andalusia II. Abdurrahman was sent to the embassy committee tried to provoke them against the Abbasids. However, while the Emperor took such measures against the Islamic world, he could not hide his admiration for the Islamic world. One of the most obvious examples of this is the fact that Abbasid caliphs built a palace similar to their palaces, followed by portrayal policies, and wandered among the people in the garb like the Abbasid Caliph Harun Reşid. For this reason, the Emperor Theophilos, as an emperor known for his admiration in the Islamic world, has been recorded in history.

Keywords: Eastern Roman Empire, Theophilos, Islamic World, Abbasid, Andalusia.

\section{Giriş}

Roma İmparatorluğu'nun sınırlarının genişlemesi ve buna bağlı olarak merkezi otoritenin zayıflaması gibi nedenlerden dolayı yönetimi kolaylaştırmak amacıyla İmparator Büyük Konstantinos'un imparatorluk merkezini İstanbul'a taşıması imparatorluğun ikiye ayrılmasının başlangıcı olmuştur. ${ }^{1}$ Sonraki dönemlerde Got ve Germen kavimlerin isyanları, Kavimler Göçü gibi olayların etkisiyle imparatorluğu batı yarısı ayakta kalmayı başaramazken, doğu yarısı jeopolitik konumu, diplomatik ve siyasi ilişkilerde ustaca tavrı nedeniyle varlığını sürdürmeyi başarabilmiştir. Ancak Doğu Roma İmparatorluğu bu hayatta kalma mücadeleleri sırasında doğudan, kuzeyden ve güneyden bir çok askeri ve siyasi tazyike maruz kalmıştır. Bunlardan bir kısmı imparatorluğun kuzeybatı kesimlerinde kendilerini gösteren Got ve Germen kavimler, diğerleri Kavimler Göçü ve sonraki dönemlerde gelen Hun, Avar, Bulgar, Peçenek, Kuman, Kıpçaklardan oluşan Türk kavimlerinin saldırısıdır. İmparatorluk doğuda ise başlangıçtan 627 yılına kadar Sasaniler ile çetin mücadeleler verirken bu yılda yapılan Ninova Savaşı ile beraber Sasani tehlikesi atlatılmıştır. Hatta Sasanilerin aldığı Suriye, Mısır, Filistin gibi topraklar yeniden ele geçirilmiştir. ${ }^{2}$ Ancak Sasani tehlikesi bertaraf edildikten hemen sonra doğu sınırlarında bir başka düşman daha uzun süreli ve daha büyük tehlike arz ederek ortaya çıkmıştır.

Hz. Muhammed(S.A.V) hayatta iken İslam dini Arap Yarımadası'nın dışına taşmaya başlamıştı. Hz. Muhammed(S.A.V), Doğu Roma İmparatoru Herakleios'a(610-641) bir mektup yazarak onu islama davet etmiş ancak red cevabı almıştır. Bu diplomatik temasın ardından Hz. Muhammed(S.A.V)'in gönderdiği bir elçinin Doğu Roma toprağı olan Suriye'de öldürülmesi üzerine M. 629'da İslam orduları Doğu Roma ordularıyla karşılaşmıştır. Bu ilk fiili karşılaşmadan sonra 630 yılında Doğu Roma'nın yeni bir ordu gönderdiği söylentisi boşa çıkmış ve Müslüman ordusu Tebük seferinden geri dönmüştür. ${ }^{3}$

634 yılında Hz. Ebubekir döneminde Doğu Roma'ya karşı yapılan Ecnadeyn Savaşı'nda Doğu Roma orduları yenilgiye uğratılınca Suriye ve Filistin kapıları İslam ordularına açılmıştır. ${ }^{4}$ Hz. Ömer döneminde devam eden fetihler sonucunda Dımaşk(Şam), Hama, Humus gibi şehirleri kaybeden Doğu Roma İmparatorluğu 20 Ağustos 636 yılında yapılan Yermük Savaşı ile Sasanilerin elinden aldıkları Suriye'yi bu kez İslam dünyasına terk etmek zorunda kalmışlardır. ${ }^{5}$ Daha sonra 642 yılında Mısır gibi büyük bir tahıl ambarını da kaybeden Doğu Roma İmparatorluğu ekonomik anlamda da oldukça zor bir duruma düşmüştür. Hz. Osman

\footnotetext{
${ }^{1}$ Alexander A. Vasiliev, Bizans Imparatorluğu Tarihi, Alfa Yay., İstanbul, 2016, s.74-75.

${ }^{2}$ Vasiliev, age, s.234.

${ }^{3}$ Casim Avc1, İslâm-Bizans İlişkileri(610-847), Türk Tarih Kurumu Yay., Ankara, 2015, s.52-53;Adem Apak, Ana Hatlarıla İslâm Tarihi(Hz. Muhammed(s.a.v) Dönemi), C.I., Temel Kültür Dizisi Yay., İstanbul, 2015, s. 349-351.

${ }^{4}$ Adem Apak, Ana Hatlartyla İslâm Tarihi(Hulefâ-i Râşidîn Dönemi), C.II., Temel Kültür Dizisi Yay., İstanbul, 2015, s.81.

${ }^{5}$ Avc1, age, s.54.
} 
döneminde Misır valisi Abdullah b. Sa'd b. Ebu Serh 647 yılında Trablusgarb'tan Tunus'a kadar uzanan önemli fetihler gerçekleştirmiştir. Suriye Valisi Muaviye ise Ermenistan ve Anadolu'ya akınlar düzenleyerek Kayseri'yi işgal etmiştir. 649 yılında Kıbrıs'a ilk deniz seferini düzenleyerek adanın merkezi Konstantia'yı ele geçirmiştir. Bu gelişmeler üzerine bir yandan doğu sınırlarında Arapların bir yandan Balkanlar'da Türklerin tazyiki altında kalan Doğu Roma İmparatorluğu 650 yılında Şam Valisi Muaviye ile belirli bir vergi karşıllı̆ında barış anlaşması yaparak tehlikeyi bir süreliğine de olsa atlatmaya çalışmıştır. ${ }^{6}$

Hz. Osman'ın öldürülmesinden sonra İslam dünyasında başlayan iç çekişmeler fetih hareketlerinin durmasına neden olmuştur. Bunu firsat bilen Doğu Roma İmparatoru II. Konstans Müslüman Araplar üzerine bir ordu göndermiştir. Ancak iç karışıklıklar nedeniyle Doğu Roma İmparatorluğu ile mücadele edemeyeceğini anlayan Muaviye imparatora bir miktar vergi ödemeyi kabul etmiştir. Daha sonra Muaviye 661 yılında Dımaşk merkez olmak üzere Emevi Devleti'ni kurmaya muvaffak olmuştur. ${ }^{7}$ Bundan sonra yarıda kalan fetih hareketlerine hız vermeye karar veren Muaviye Doğu Roma İmparatorluğu topraklarına yeniden yönelmiştir. $\mathrm{Bu}$ dönemde Müslümanlar, tam üç kez İstanbul'u kuşatarak Doğu Roma İmparatorluğu'nu tehdit etmeyi başardılar ancak bu kuşatma hareketleri uzaklık, ulaşım sıkıntısı, yiyecek ve erzak tükenmesi, Grejuva Rum ateşi, iklim gibi şartlar nedeniyle başarıya ulaşamamıştır. ${ }^{8}$

Emevi Devleti'nin bir çöküş dönemi içine girmesi Bizans'ın doğu sınırlarında bir süre rahatlamasına neden olmuştur. Bunu firsat bilen Doğu Roma İmparatoru V. Konstantinos(741775) kuzey Suriye'deki Arap topraklarına girmiş ve Maraş (Germanikeia)'ı ele geçirmiş ve Doğu Roma'nın kolonizasyon politikasına uygun olarak çok sayıda esiri Trakya bölgesine yerleştirmiştir. Diğer yandan Araplara karşı denizde de harekete geçen Doğu Roma İmparatorluğu 747 yılında Kıbrıs yakınlarında bir Arap donanmasını imha etmiştir. 752 yılında Armenia ve Mezopatamya bölgelerine yapılan seferler de başarıya ulaşmış ve Theodosiopolis(Erzurum), Melitene(Malatya) gibi şehirler ele geçirilmiş ve yine buralardan alınan esirler Trakya'ya Bulgar sınırlarına yerleștirilmiştir. ${ }^{9}$ Ancak çok kısa bir süre sonra bu alınan yerler bir başka İslam devleti olan Abbasilerin ortaya çıkışı ve yükselişi ile yeniden kaybedilmiştir. Doğu Roma İmparatorluğu doğu sınırlarında Araplarla mücadelelerine devam etmek zorunda kalmıştır. ${ }^{10}$ Nitekim, İstanbul surları yeniden tehdit altına girmeye başlamış ve 781-782 yıllarında Abbasi Halifesi Mehdi Billah'ın (775-785) oğlu Harun Reşid komutasında bir ordu Üsküdar'a gelmiştir. Bu sırada bu sırada İslam ordularına karşı mukavemet gösteremeyecek durumda olan İmparatoriçe İreneAbbasilere y1lda iki kez 70.000 dinar ödemeyi ve Abbasi ordusunun geri dönüşü sırasında ihtiyaçlarını karşılamayı taahhüt etmek zorunda kalmıştır. ${ }^{11}$

Doğuda Abbasi Devleti en parlak devrini yaşamaya başladığı bu dönemde İslam orduları imparatorluk topraklarının derinlerine girmeye başlamıştır. Thrakesion(Trakya) theması topraklarında Doğu Roma ordularına karşı çok büyük bir zafer kazanan Abbasiler karşısında barış istemek zorunda kalan imparatorluk haraç ödemeyi kabul etmiştir. Ancak bu durum bile sukunetin uzun sürmesini sağlayamadığı gibi kısa bir süre sonra Abbasiler Anadolu'ya yeniden akınlar düzenlemeye başlamışlardır. Diğer yandan batıda Bulgarlarla yapılan savaşlarda alınan yenilgiler dolayısıyla da Bulgarlara haraç ödemek zorunda kalan imparatorluk doğuda ve batıda

\footnotetext{
${ }^{6}$ Age, s.59; Apak, age, s. 196.

${ }^{7}$ Apak, C.III(Emeviler Dönemi), s.32.

${ }^{8}$ Vasiliev, age, s. 275.

${ }^{9}$ Apak, C.IV.(Abbasiler Dönemi), s.90-91.

${ }^{10}$ Ostrogorsky, age, s.155-156; Avc1, age, s.80.

${ }^{11}$ Vasiliev, age, s.278;Apak, age, s.154.
} 
askeri, ekonomik ve siyasi bakımdan iyice sıkışık bir döneme girmiştir. ${ }^{12}$ İmparatoriçe İrene'nin yanlış politikalarını ortadan kaldırmak isteyen I. Nikephoros(802-811) ise Abbasilere ödenen vergiyi durdurmuştur. Ancak İslam ordularının ilerleyişi karşısında bu tutumundan vazgeçmek zorunda kalan İmparator yine barış teklif etmek ve vergi ödemek zorunda kalmıştır. Hatta kendisi ve oğlu için her y1l baş vergisi dahi vermeyi kabul ederek küçük düşürücü bir duruma dahi düşmüştür. Ancak Halife Harun Reşid'in 809 yılında ölümü ve bundan sonra Abbasi Devleti içinde çıkan karışıklıklar bir müddet rahatlamaya sebep olmuştur. ${ }^{13}$

Harun Reşid'in ölümü üzerine başlayan iç mücadeleler nedeniyle yıpranmaya başlayan Abbasiler şimdilik Doğu Roma için bir tehdit olmaktan çıkmıştır. Bu nedenle dış siyasette tehlike beklenmeyen bu döneme İmparator V. Leon'un(813-820) tasvir kırıcılık politikaları damgasını vurmuştur. İlk kez III. Leon(717-741) döneminde başlatılan bu anlayışa göre tasvirler önünde ibadet etmek yasaklanmış, kiliseler ve manastırlar gibi dini ibadet yerlerinde bu tasvirlerin ve resimlerin kullanılması men edilmiştir. ${ }^{14}$ Doğu Roma İmparatorlarının III. Leon başta olmak üzere tasvir karşıtı tutum izlemelerinin en önemli nedenlerinden biri de İslam dünyasındaki uygulamalardan etkilenmiş olmalarıdır. Nitekim Anadolu'ya sürekli olarak giren ve hatta İstanbul'a kadar uzanan Araplar bu süreçte Doğu Roma İmparatorluğu'na yalnız silahlarını değil aynı zamanda kültürlerini de uzatmışlardı. Araplar İslamiyet öncesi dönemde kendi elleri ile yaptıkları ve genellikle insan yüzlerinden oluşan putlara taptıkları gibi| İslamiyet'le birlikte bu putlara tapınılması yasaklanmış ve bir süre sonra bu putlara karşı eğreti duymaya başlamışlardı. Böylece İslam dünyası içerisinde başlayan tasvirler aleyhindeki bu gelişmeler İmparatorluğun doğu sınırlarında saf ruhaniyete bürünmek isteyen Hıristiyan imanı ve resim düşmanı mezhepler ve bunların öğretileri ile bütünleşerek tasvir kırıcılılık döneminin başlamasına neden olmuştur. ${ }^{15}$ Buradan anlaşıldığ üzere tasvir karşıtı politikalar yürütecek olan imparatorlar genellikle doğu kökenli ve Araplarla bir şekilde münasebeti olan ve İslam dünyasından etkilenen imparatorlar olmuştur. Örneğin III. Leon'un başlattığı tasvir kırıcı hareket bazı imparatorlar tarafından devam ettirilirken mesela Atina kökenli bir imparatoriçe olan İrene tarafından tam tersine tanınmamış ve tasvirler yeniden serbest bırakılmıştır. Bir başka İmparator Theofilos(829-842) ise İslam dünyasına duyduğu hayranlık nedeniyle yeniden tasvir karşıtı bir politika izlemiştir. ${ }^{16}$ Nitekim İmparator Theofilos'un bu hayranlığı dış politikada da etkilerini göstererek imparatorluğun Abbasiler ile ilişkileri noktasında etkili olmuştur. Bu çalışmamızda İmparator Theofilos'un İslam dünyası ile siyasi, sosyal ve kültürel ilişkileri üzerinde durulacak olup aynı zamanda Endülüs Emevileri ile Abbasilere karşı kurmak istediği ittifak çabaları anlatılacaktır.

Theofilos'un babası olan İmparator II. Mikhail(820-829)'in tahta çıkmasıyla birlikte Doğu Roma İmparatorluğu'nda İsaurian(İsauralılar) hanedanlığ 1 sona ererek Amorion hanedanlığ 1 başa geçmiştir. ${ }^{17} \mathrm{Bu}$ dönemde Doğu Roma İmparatorluğu ile Müslüman Araplarla yapılan mücadelelere devam edilmiştir. Abbasi Halifesi bu dönemde her ne kadar devletindeki iç karışıklıklar nedeniyle Doğu Roma'ya karşı bir taarruza geçemeyecek durumda olmasına rağmen Doğu Roma İmparatorluğu İslam dünyasının diğer kısımları tarafından büyük tehlikelere maruz kalmıştır. 816 yılında Mısır'ı ele geçirerek burada geçici bir hakimiyet kuran İspanya'lı Arap Muhacirler bu kez Girit Adası'nı işgal etmiştir. Böylece İmparatorluk Doğu Akdeniz'de bulunan önemli bir stratejik üssünü kaybetmiştir. Bu tarihten itibaren yaklaşık bir

\footnotetext{
12 Ostrogorsky, age, s.169-170.

${ }_{13}^{13}$ Apak, age, s.154-155;Ostrogorsky, age, s.182-183.

${ }_{14}^{14}$ Ostrogorsky, age, s. 149-151; Vasiliev, age, s.292-300.

${ }^{15}$ Ostrogorsky, age, s. 150.

${ }^{16}$ Vasiliev, age, s.329-331.

${ }^{17}$ Avc1, age, s.90.
} 
buçuk asır kadar bu ada tüm müdahalelere rağmen Arapların elinde kalmıştır. 827 yılında Sicilya Adası'nı da ele geçiren Araplar böylece Doğu Roma İmparatorluğu'nun Akdeniz ve Adriyatik bölgesindeki gücünü iyice sarsmıştır. Doğu Roma İmparatorluğu Emevi Devleti’nin yıkılışından sonraki dönemde donanma gücünü ihmal etmiş olmanın faturasını böylece ödemiştir. Diğer yandan II. Mikhail dönemi Doğu Roma nüfuzunun Adriyatik sahillerinde büyük ölçüde gerilediği bir devir olarak tarihe geçmiştir. ${ }^{18}$

\section{1. İmparator Theofiolos Dönemi’nde(829-842)Abbasiler İle İlişkiler}

İmparator II. Mikhail'den sonra yerine oğlu Theofilos(829-842) geçmiştir. İmparator Theophilos, Arapça kaynaklarda Tufil adıyla anılmıştır. ${ }^{19}$ Babası II. Mikhail, okuma ve yazmayı sonradan öğrenen ve çok başarılı bir imparator olmamasına rağmen Theofilos daha iyi bir tahsil ve terbiyeye sahip ve ayn zamanda bilim ve sanata daha ilgili bir imparatordu. ${ }^{20}$ Dolayısıyla kendini yüksek seviyede yetiştirmeyi başaran bu imparator o zamanların bilim ve kültür alanında en çağdaş ve en modern bir merkezi olan Bağdat'tan yayılan bilimsel, kültürel ve sanatsal faaliyetlere karşı da büyük bir ilgi göstermiştir. ${ }^{21}$ Nitekim İmparator Halife Harun Reşid'in şahsiyetinden etkilenerek, tebdili kıyafetle halkın arasında dolaşarak onların sıkıntılarını yakından dinler ve halkın şikayetlerine göre suçlu olan devlet adamlarını makam ve mevkilerine bakmaksızın cezalandırmıştır. ${ }^{22}$

İmparator Theofilos'un İslam dünyasından bilimsel ve kültürel alanda etkilendiği gibi dini anlamda da etkilendiği gözlemlenmektedir. Özellikle bu dönemde Doğu Roma'nın dini hayatında tartışılması geride bırakılmış tasvir kırıcılık faaliyetlerinin yeniden gündeme gelmesi, İmparatorun tasvir karşıtı bir tutum alması bu fikrimizi oldukça desteklemektedir. Zira onun saltanat dönemi Doğu Roma İmparatorluğu'nun Arap kültürünün etkisine en şiddetli bir şekilde maruz kaldığ 1 dönem olmuştur. Nitekim ünlü Bizans tarihçisi Ostrogorsky, İmparatorun bu yanı ile ilgili şu ifadeleri kullanarak bunu ispat etmektedir: "Theofilos önemli bir hükümdar değil fakat en yüksek derecede ilgi çekici bir şahsiyet idi. Bir romantikti ve ölmek üzere olan tasvir kirıcılığa kendisini büyük bir şevk ile verişinde olduğu gibi, Arap dünyasının en yüksek devresi artık arkada kalmış olan sanat ve kültürüne karşı duyduğu hayranlıkta da bu romantizm mevcuttur. İnanç taassubu içinde işlemekten kendisini alamadı̆̆ nefret edilecek zulum hareketlerine rağmen, insan olarak çekici bir yanı vardı;onun şahsı etrafinda efsanelerin vücut bulmuş olmasina hayret etmemelidir. İdeal bir hükümdar olmak arzusundaydl;ruhu, biraz da sahneye yakışır pozlarla izhar ettiği kuvvetli bir adalet duygusu ile dolup taşıyordu....". 23

İmparator Theophilos döneminde Abbasi-Doğu Roma ilişkileri kapsamında birçok olay yaşanmıştır. Dolayısıyla hem Abbasi tarihinde hem de Doğu Roma İmparatorluğu tarihinde bahsi geçen dönem İslam-Bizans ilişkileri açısından büyük rol oynamıştır. Bu dönemde Me'mun ve Mutasımbilllah gibi güçlü halifeler Abbasi tahtına çıkmıştır. ${ }^{24} \mathrm{Me}$ 'mun döneminde İslam dünyasındaki Şî̂lik ve Sunnîlik çatışmaları Abbasî ülkesinin birçok bölgesinde huzursuzluklara ve isyanlara yol açtı. Me'mun'un içerideki bu mücadele süreci onu Doğu

\footnotetext{
${ }^{18}$ Ostrogorsky, age, s. 192-193.

19 İbn-Esir, Ali b. Muhammed, El-Kâmil fil-tarih, Thk:Abdullah El-Kadî, C,VI, Daru'l-Kutup Yay., Kahire, 1987, s.218.

${ }^{20}$ Ostrogorsky, age, s.193.

21 Age, s.193.

22 İbn-Esir, age, s.218;Ostrogorsky, age, s.193.

${ }^{23}$ Ostrogorsky, age, s.193.

${ }^{24} \dot{I}$ bn-Esir, age, s.218.
} 
Roma İmparatorluğu ile savaşmaktan alıkoymuş ve olası bu mücadeleler hükümdarlığının son y1llarına kalmıştır. ${ }^{25}$

Müslümanlar ile Bizanslılar arasındaki mücadele her iki tarafın da iç meselelerinden dolayı 25 yıl boyunca sessizlik içine gömülmüş ancak Me'mun'un hilafetinin son yıllarında tüm şiddeti ile başlamıştır. Nitekim Halife Me'mun artık iç meseleleri halletmiş Doğu Roma'ya karşı uzun süreden beri durmuş olan mücadeleyi tekrar ele alabilecek duruma gelmişti. Diğer yandan Doğu Roma, Arap fetihleri nedeniyle Sicilya'da da savaşmak zorunda olduğundan ve burada Arap fetihleri hızlı bir ilerleyiş gösterdiğinden askeri kuvvetlerini Anadolu'ya toplayacak durumda değildi. Dolayısıyla Halife Me'mun Bizans'ın içinde bulunduğu bu durumdan yararlanmak için en uygun zamanı yakalamıştı. 830 yılında başlayan bu savaşların nedeni ise Bizans'ın sınırlarını zayıflatarak Sugur ve gerisindeki bölgeyi tehlikelerden korumak ve Bizanslıların Babek'i kışkırtmalarına engel olmaktı. ${ }^{26}$ Halife Me'mun döneminde bazı putperestlik adetlerinin geri getirilmesini isteyen Babek El-Haramî tarafından bir isyan çıkarılmıştır. ${ }^{27}$ Halife bu isyanı bastırmak için hareket etmeye başlayınca Babek El Haramî, İmparator Theophilos ile işbirliği yaparak kendisine bağl1 15.000 kişi ile birlikte İmparatorun hizmetine girmiştir. İmparator da kendi hizmetine girenleri sınırda Abbasilere karşı kullanarak görevlendirmiştir. ${ }^{28}$ Ancak Me'mun'un başlattı̆ğ bu ilk sefer Müslümanların başarısıyla sonuçlanmış ve Me'mun seferden sonra kışı geçirmek üzere Şam'a dönmüştür. ${ }^{29}$

831 yılında İmparator Theophilos harekete geçerek İslam ordularını bozguna uğratmış ve 1600 kişiyi öldürüp 7000 kişiyi esir almıştır. Aynı yıl harekatına devam eden imparator Theophilos, Abbasi sınırına doğru hareket ederek büyük bir askerî hamle gerçekleştirmiştir. Buna karşı Halife Me'mun hem Doğu Roma'nın Babek isyanına verdiği desteği ortadan kaldırmak hem de bu sayede Doğu Roma sınırından gelecek olası tehlikelerin önüne geçmek için ordusuyla birlikte Doğu Roma ordusuna karşı yola çıkmış ve iki ordu arasında meydana gelen savaşta Müslüman ordusu galip gelmiştir. ${ }^{30}$

İmparator Theophilos bu mağlubiyetten sonra pes etmeyerek 832 y1lında ordusuyla birlikte Abbasi topraklarına doğru yola çıkmıştır. Birkaç Müslüman köyü ele geçirmesinin ardından

\footnotetext{
${ }^{25}$ Nahide Bozkurt, "Me'mun”, Diyanet Işsleri İslam Ansiklopedisi, C.29, Ankara, 2004, s.101-102;Apak, age, s.176179.

${ }^{26}$ Bozkurt, agm., s.103; Ostrogorsky, age, s.195.

${ }^{27}$ Abbasî ihtilalinin önemli kahramanlarından olan Ebu Müslim'in idam edilmesi üzerine Horosan'da Hürremiye adlı bir mezhep gelişmeye başlamıştı. İslamiyet, Zerdüştlük ve Maniheizm'in karışımından meydana gelen bu mezhep yandaşları, hoş olan ve başkasına zarar vermeyen her şeyi yapmayı olağan sayıyorlardı. Üyelerinden bir kısmı Ebu Müslim'in öldüğüne inanmayıp kendisinin "dünyada adaleti yaymak üzere" tekrar geleceğini düşünüyorlardı ve bunlara "Müslümiyye" adı verilmişti. Diğer bir kısmı ise Ebu Müslim'in bütün yetkilerinin kızı Fatma'ya geçtiğini ve onun imam olduğunu kabul ediyorlardı bunlara da "Fatimiyye" denmiştir. Me'mun döneminde bu mezhebin başına Babek El-Haramî geçmiştir. Babek bu mezhebin yaygın olduğu yerlerde özellikle hilafet ve devlet müessesesine karşı eskiden beri husumet besleyen dağlı kabileleri etrafında toplayarak çok tesirli bir isyan başlattı. Me'mun'un hakimiyetinin temellerini yıkmak amacı taşıyan bu isyan Bizanslılar'ın desteklemesiyle iyice büyüdü. Me'mun döneminde mücadele edilen fakat tam olarak bastırılamayan isyan Mutasım döneminde büyük bir ordu ile hareket edilerek 60.000 kişinin öldürülmesine neden oldu. Ancak Babek ele geçirilemedi. Halife Mutasım, Afşin ve Büyükboğa gibi komutanları da Babek'i yakalamaları için görevlendirdi. Bu komutanlar da Babek'in hazinelerini ele geçirmelerine rağmen Babek'in kaçması üzerine kendisini yakalayamadılar. 837 yılında onu tanıyan bir çobanın Ermeni prensine haber vermesiyle yakalanarak Afşin'e teslim edildi. Daha geniş bilgi için bkz. Muhammet Salim Kerim, El-Şuubiyye Neşeteha ve Tetavvuruha, Daru'l-Cumhuriye Yay., Misrata, 2004, s. 47;Bahriye Üçok, İslam Tarihi Emeviler-Abbasiler, Milli Eğitim Basımevi, Ankara,1978, s.113-114; Apak, age, s.180-186.

${ }^{28}$ Muhammed b. Cerir El-Tabarî, Terih El-Russul ve El-Mulûk, Thk: Mohammed İbrahim, C.IX., Daru'l-Maarif Yay., Kahire, 1967, s.56.

${ }^{29}$ Bozkurt, agm., s.103.

${ }^{30}$ El-Tabarî, age, s.56;Apak, age, s.195-196.
} 
Me'mun'a bir elçi gönderip barış istemiştir. Bu kez İslam ordularının başarılı ilerleyişi üzerine İmparator Theophilos, Halife Me'mun'a 100.000 dinar vermeyi ve 7000 esiri serbest birakmas1 karşıllığında aldıkları yerlerin iadesini ve 5 yıllık barış teklifinde bulunmuştur. ${ }^{31}$ Me'mun İmparatorun teklifini kabul etmemiş ve 833 yılında kardeşi Mu'tasım ve oğlu Abbas ve kumandanlarına daha büyük bir sefer hazırlığı emrini vermiştir. Bu sefer ele geçirdiği yerlerin imar edilmesi ve bölgede Müslüman halkı yerleştirme düşüncesi ile daha kapsamlı bir harekât planlanmıştır. Halife tarafından tüm barış teklifleri geri çevrilen İmparator Theofilos yeniden bir mektup yazarak Müslüman esirleri serbest bırakmak, İslam ordusunu tüm yiyecek ihtiyaçlarını karşılamak, tahrip edilen Suğur bölgesindeki kaleleri tamir etmek gibi tekliflerle barış istemiştir. Ancak Me'mun Bizans elçisi geldiğinde çadırına girip iki rekat namaz kıldıktan sonra savaştan başka bir yol olmadığı şeklinde cevap vermiştir. ${ }^{32}$ Doğu Roma ordularını birçok kez yenilgiye uğratan Halife, korunaklı olan Lü'lü' kalesini 3 ay kuşatmış ve kaleyi ele geçirmeyi başarmıştır. Ancak bu olaydan sonra hastalanmış ve Şam'ın kuzeyinde bulunan Rakka'ya gitmiştir. Burada 9 Ağustos 833 tarihinde vefat etmesiyle Me'mun'un planları yarıda kalmış ve Daru'l-hakan'da toprağa verilmiştir. ${ }^{33}$

Halife Me'mun döneminde Bizans-Abbasî savaşları değişik bir yol izleyerek devam etmiştir. Bazen Bizans İmparatoru İslam topraklarına girerken ve imparator İstanbul'da muhteşem kutlama törenleri yaparken bazen de Müslüman Araplar Bizans topraklarına giriyorlardı. Bunun üzerine imparatorun maneviyatı sürekli olarak bozulmuş ve halifeye zengin hediyeler sunarak barış teklifleri sunan elçilik heyetleri göndererek tehlikeyi bertaraf etmeye çalışmıştır. ${ }^{34}$

Me'mun döneminde Bizans ile Abbasiler arasında savaşlar olmasına rağmen ilmî ve kültürel alanda işbirliği de yapılmıştır. Bu bağlamda her iki taraf birbirine elçilik heyetleri ve hediyeler göndererek bağlantı kurmaya çalışmıştır. Örneğin İmparator Theophilos tahta çıkınca hocası Synkellos Ioannes Grammatikos'u(Yuhanna En-Nahvi) Me'mun'a elçi olarak göndermiş ve çeşitli hediyeler takdim etmiştir. Bu ziyareti sırasında Ioannes, Bağdat sarayını çok beğenmiş ve gördüklerini imparatora anlatmıştır. İmparator Ioannes'in anlattıklarından etkilenerek bu saraya benzer bir sarayın yapılmasını emretmiştir. Nitekim bugün İstanbul'un Küçükyalı semtinde sadece kalıntıları bulunan Bryas sarayı inşa edilmiştir. Bu ise İmparatorun Abbasî kültürel yaşamına ve medeniyetine hayranlığını göstermektedir. ${ }^{35}$ İmparator Theofilos'tan sonra Halife Me'mun da imparatora bir elçi yollamıştır. Bu elçinin Müslüman esirleri ziyaret ederek onların durumunu halifeye anlattığı halifenin de esirlerin serbest bırakılmasını sağladığ 1 rivayet edilmiştir. Nitekim İmparatorlar ile Halifeler arasındaki hediyeleşmeler şan ve şeref göstergesi olduğu için elçilik heyetlerine karşılıklı olarak pahalı hediyeler sunulmuştur. Bir defasında Me'mun kendisine getirilen hediyelerin yüz katının imparatora gönderilmesini istemiş ve "İmparator İslam'ın izzetini ve Allah'ın bize vermiş olduğu nimetleri görsün" demiştir. Ayrıca Bizanslılar için en değerli hediyelerin misk ve samur olduğunu öğrenen Me'mun hediyelere bunların da eklenmesi emrini vermiştir. ${ }^{36}$ Diğer yandan Halife Me'mun imparatora mektup yazarak eski Yunanca yazmalardan bir kısmının Bağdat'a gönderilmesini istemiştir. Başlangıçta buna karşı çıkan imparator daha sonra bu isteği kabul etmiştir. Halife bunun üzerine Haccâc b. Matar, İbn Batrîk ve Yuhannâ b. Mâseveyh gibi bazı bilim adamlarını İstanbul'a göndermiştir. Bu bilim adamları aracılığıyla getirilen felsefe, matematik, tıp ve

\footnotetext{
${ }^{31}$ Bozkurt, ag.m., s.103; Avc1, age, s.91.

${ }^{32}$ Avc1, age, s.92;Apak, age, s.197.

${ }^{33}$ El-Tabarî, age, s. 629; Bozkurt, agm., s.103.

${ }^{34}$ Ostrogorsky, age, s.195.

${ }^{35}$ Bozkurt, ag.m., s.103: Avc1, age, s.90-91; Vasiliev, age, s.345.

${ }^{36}$ Avc1, age, s.92.
} 
musikîye dair eserler Arapça'ya çevrilmiştir. ${ }^{37}$ Bağdat'a getirilen eserler arasında Platon, Aristo, Hipokrat, Galenos, Öklid, Batlamyus ve tabiat bilimcilerine ait olanlar da vardi. Matematikçi Apollenias'un Kitabu'l-Mahrûtât adlı eserinin 1.Bölümü de Arapça'ya çevrilen eserler arasında yer almaktaydı. ${ }^{38}$ Doğu Roma'da bulunan eski Yunan bilimine ait eserlere büyük ilgi duyan ve bir kısmını ülkesine getiren Halife Me'mun bilim adamlarına da önem vermiştir. Nitekim şöhreti öğrencileri aracılığıyla Bizans sınırlarının dışına taşıp Bağdat'a kadar uzanan Matematik, Felsefe ve Astroloji alimi Leon bu noktada Halife'nin dikkatini çekmiştir. Leon birbirinden belli uzaklıktaki tepeler üzerinde oluşturulan 1 şık işaretleri sayesinde Arap akınlarını kısa sürede başkente bildirmek üzere bir mekanizma icad etmiştir. $\mathrm{Bu}$ mekanizma sayesinde Mutasım dönemindeki Amorion(Amûriye) ${ }^{39}$ kuşatmasında olumlu sonuçlar elde edilmiştir. Ayrıca Leon daha bol ürün elde etmek amacıyla da bir takım yöntemler geliştirerek üretime katkıda bulunmuştur. Leon'a mektup yazarak sarayına davet eden Me'mun bu girişiminde başarılı olamamıştır. Çünkü bu mektuptan haberdar olan İmparator Theophilos Leon'un hem ücretini arttırmış hem de onu İstanbul'un önemli kiliselerinden birine tayin etmiştir. Bunun üzerine Halife Me'mun bizzat imparatora mektup yazarak kısa bir süre için dahi olsa Leon'un Bağdat'a gönderilmesini rica etmiştir. Mektubunda imparatora isteğini yerine getirdiği takdirde bunu bir dostluk işareti sayarak kalıcı bir barış imzalanacağına söz vermiş ve bunun yanı sıra 2000 dinar teklif etmiştir. Bütün bu girişimlerine rağmen Me'mun imparatordan olumlu bir cevap alamamıştır. ${ }^{40}$

Me'mun'un ölümü sırasında Bizans topraklarında kardeşi ile birlikte seferde bulunan Mutasım Billah 833 yılında halife seçilmesinin ardından İmparator Theofilos ile bir anlaşma yaparak Bağdat'a dönmüştür. Halifeliğinin ilk yıllarında başta Babek meselesi olmak üzere, kardeşinin ölümü üzerine isyana kalkışan Basra ile Vasıt arasında yaşayan Zutt'lara ayrıca Mutezile taraftarı tutumundan ve Türk ve berber askerlerine karşı halkın öfkesi gibi mevzular ile meşgul olmuştur. Daha sonraki yıllarda Bizans ile savaşlar yeniden başlamıştır. ${ }^{41}$

Mutasım hilafet makamına geldiğinde Babek el-Haramî isyanı bitmek üzeriydi. Ancak İmparator Theophilos Babek el-Haramî'ye yardım ederek daha önce Halife Mutasim ile yaptığ 1 anlaşmayı bozmuştur. 837 yılında ordusunun başında yola çıkarak Fırat nehrini geçmiş ve buradaki Müslüman memleketlerini istila ederek ardından Zabatra ${ }^{42}$ kalesine saldırmıştır. Kalede katliam yaparak 10.000 Müslüman öldürülmüştür. Bunun yanında Samsat ve Malatya şehirlerine de saldırarak yıkan İmparator kuzey Suriye ve El-Cezire'yi büyük ölçüde tahrip etmiştir. ${ }^{43} \mathrm{Bu}$ zaferin ardından İmparator Theofilos, Halife Mutasım’a tehditkâr bir mektup yazmış bunu okuyan Halife ise oldukça kızarak "Bismillâhirrahmanirrahîm. Mektubunu okudum; ne demek istediğini anladım. Cevabını duymakla kalmayacak, bizzat göreceksin. Kâfirler bu dünyanın sonunun kime ait olduğunu yakında bileceklerdir" şeklinde cevap vermiştir. $^{44}$

\footnotetext{
${ }^{37}$ Apak, age, s.207;Avc1, age, s.92-93.

${ }^{38}$ Bozkurt, agm., s.103-104.

39 Eski Yunanca kaynaklarında Amorion, Arap/İslam kaynaklarında "Ammuriye" ya da "Amûriye" olarak geçen bu yer bugün kü Afyon şehrinin Emirdağ İlçesine yaklaşık $13 \mathrm{~km}$ uzaklıkta bulunan bir yerdir. Bkz. Besim Darkot, “Ammuriye” Milli Eğitim Bakanlığı İslam Ansiklopedisi, C.1, İstanbul,1970, s.411-412.

${ }^{40}$ Casim Avcı, "Abbasi Halifesi Me'mun Döneminde Bizans'la İlişkiler”, İSAM, C.IV, S.2, 2011, s.94-100; Vasiliev, age, s.344-345.

${ }^{41}$ Mutasım döneminde yaşanan dahili proplemler hakkında daha geniş bilgi için bkz. Apak, age, s.217-234;K.U. Zettersteen, "Mu'tasım”, Milli Eğitim Bakanlığı İslam Ansiklopedisi, C.8, İstanbul, 1970, s.748-749.

${ }^{42}$ Zabatra: Malatya ve Samsat arasında yer alan bir şehirdir. Bkz. İbn-Esir, age, s.218.

${ }^{43}$ El-Tabarî, age, s. 52,55; K.U. Zettersteen, agm., s.748-749; Vasiliev, age, s.320;Apak, age, s.234-235.

${ }^{44}$ Avc1, age, s.93-94.
} 
Mutasım bu katiam haberini aldıktan sonra gözde komutanlarını toplayarak Bizansların en korunaklı şehirlerini sormuştur. Komutanlar, günümüzde Afyon sınırları içinde bulunan Amorion şehrinin en korunaklı şehirlerden biri olduğunu söylemişlerdir. Bunun üzerine Mutasım, Amorion şehrini yıkmaya ve İmparator Theophilos'un heybetini ortadan kaldırmaya yemin etmiştir. Mutasım ilk iş olarak Babek'in ivedilikle öldürülmesini komutanlarına emretmiştir. Böylece kısa zaman içinde Mutasım'ın askerleri Babek'i öldürmüş ve fitne ortadan kaldırılmıştır. ${ }^{45}$

838 yılı Nisan ayında Mutasım 120.000 kişilik ordusuyla Samarra şehrinden yola çıkmıştır. Mutasım Amorion'u fethetmek için plan yaparak orduyu üç kısma ayırmıştır. Birinci kısmın başında kendisi, ikinci kısmın başında Afşin ve üçüncü kısmın başında Aşnas bulunmaktaydı. Her bir kısımda 33.000 asker vardı. Yapılan plana göre ise ilk hedef Ankara'dır. Ayrıca bütün ordu Ankara'da toplandıktan sonra hep birlikte Amorion'a hareket edilecekti. ${ }^{46}$

İmparator Theophilos ise M. 838 Mayıs ayında Konstantinopolis'ten hareketle yola çıktı. İmparator Halife'nin hedefinin Amorion olduğunu öğrendi ve bu sebeple şehri Müslümanlardan korumak için sınır komutanı Athius'a mektup göndererek elinden geleni yapmasını istemiştir. İmparator ordusu ile birlikte Karadeniz'e yakın olan Harsyon bölgesinde karargahını kurarak Müslüman ordusunu beklemeye başlamıştır. Ancak İmparator Müslüman askerlerinin başındaki Afşin'in Hads yolundan ilerlediğini bilmiyordu. Bu haber İmparatora geldiğinde askerleriyle birlikte Afşin komutanlığındaki Müslüman ordusuna doğru hareket etmiştir. M.838 yılının 22 Haziran günü iki ordu karşılaşmış ve şiddetli bir savaş meydana gelmiştir. Bizans ordusu sayıca çok fazla olmasına rağmen büyük ve ezici bir yenilgiye uğramıştır. İmparator bile esir düşmek üzereyken savaş alanından çekilip Dorylaeum kalesine sığınmıştır. Halife Mutasım ve Aşnas ise Ankara'ya varmış ve Zabatra ahalisinden intikam almak için şehri yıkmışlardır. Tam bu sırada Afşin askerleriyle birlikte zafer sancakları tutarak Ankara'ya varmıştır. ${ }^{47}$ Bunun üzerin Halife'den barış isteyen İmparator, 150 Bizans komutanının serbest bırakılması karşılığında her biri için 100 müslüman esirin salıverileceğini söyledikten sonra Halifeye birçok hediyenin yanında 40 kat ipek elbise gönderdiğini belirtmiştir. Halife ise barış görüşmelerine Amorion'un fethinden sonra başlanabileceğini söylemiştir. ${ }^{48}$

Böylece Ankara'yı ele geçiren İslam orduları burada birleşerek hep birlikte Amorion'a doğru hareket etmişlerdir. Bu hareket sırasında yolda bulunan bütün Bizans köyleri yıkılmıştır. Ankara'dan çıktıktan bir hafta kadar sonra İslam orduları Amorion önlerine gelmişlerdir. 1 Ağustos 838 tarihinde şehir muhasara edilmiştir. Kuvvetli surlara sahip olan şehir kale içindekilerin iyi savunma yapmaları sebebiyle başlangıç itibariyle fethedilememiş ancak nihayetinde surların zayıf bir noktası tespit edilerek 12 Ağustos 838 tarihinde fethedilmiştir. Bu sefer Müslümanların Doğu Roma'ya karşı düzenlediği en başarılı askeri harekatlardan biri olarak kabul edilmiştir. Fetihten sonra bir süre Amorion'da kalan Halife Mutasım Theofilos'un barış talep eden elçilik heyetinin isteklerini bir kez daha reddetmiştir. ${ }^{49}$ Ancak Mutasım, Amorion'da bulunduğu sırada Bağdat'ta ona karşı bir siyası komplo düzenlendiğini, yeğeni Abbas'ın tahta çıkmak için harekete geçtiğini ve kendisine karşı bir suikast tertip edildiğini öğrenmiştir. Bunun üzerine ciddi tedbirler almak gerektiği için ordusu ile birlikte Bağdat'a geri

\footnotetext{
${ }^{45}$ El-Tabarî, age,s. 56;Apak, age, s.235.

${ }^{46}$ Muhammed Suheyl Takûş, Tarih el-Devletu'l-Abbasiyye, Daaru'k-Nefâ's Yay., Beyrut, 2009, s. 147;Apak, age, s.235-236.

${ }^{47}$ El-Tabarî, age,s. 56: Takûş, age, s.149; K.U. Zettersteen,agm., s.748-749;Apak, age, s.236.

${ }^{48}$ Apak, age, s.236.

49 Age, s.236-237.
} 
dönmüştür. Dolayısıyla Mutasım'ın bu Bizans seferlerinin devamı gelmemiştir. Mutasım Bağdat'a döndükten kısa bir süre sonra M.841 yılında vefat etmiştir. ${ }^{50}$

Amorion yenilgisi İmparator Theofilos'un üzerinde derin izler bırakmış ve tek başına Arap saldırılarını bertaraf etme umutlarını kaybetmesine neden olmuştur. Ayrıca başkenti kaybetme kaygısıyla da Araplara karşı yardım istemek için yönünü batılı ülkelere çevirmiştir. Frank Kralı I.Ludwig'e(814-840), Venedik'e hatta İspanya'daki Emevi Emirliğine dahi elçiler göndererek yardım istemiştir. Ancak elçiler sıcak bir şekilde karşılanmasına rağmen İmparator Theofilos'un isteklerine olumlu cevap verilmemiştir. ${ }^{51}$

\section{2 İmparator Theofilos Döneminde Endülüs Emevi Devleti İle İlişkiler}

8. asrın başlarında tarih sahnesinde görülen Endülüs Emevi Devleti yaklaşık bir asır boyunca kendi devletlerinin kuruluşunu tamamlamak, tanzim etmek ve buna karşı çıkan ayaklanmalar ve devrimleri bastırmakla meşgul olmuştur. Ayrıca, devletlerini tehdit eden dış tehlikelere özellikle kuzey sınırlarındaki İspanyol krallıklarının tehlikesine karşı direnişe yönelmişlerdi. Bu durum Emirlik döneminde Emevi-Bizans bağlantısının gecikmesine neden olmuş ve uzun bir süreye kadar devam etmiştir. Bu nedenle Endülüs Emevi Devleti'nin kuruluşundan itibaren neredeyse bir asır geçmesine rağmen Bizans İmparatorluğu ile aralarında diplomatik bir ilişki söz konusu olmamıştır.

Emevi-Bizans ilişkileri ile ilgili elimizde bulunan ilk bilgi ise M.839 y1lında Bizans İmparatoru Theofilos(M.829-842)'un Emevi Emiri II. Abdurrahman'a (M.821-852) ${ }^{52}$ çeşitli amaç ve hedeflerine ulaşmak için görevlendirdiği elçilik heyetleri ile ilgilidir. Dolayısıyla bu ilk ilişki çağdaş tarihçilerin ilgisini azami derecede çekmiştir. ${ }^{53}$

Kaynaklarda Emevi Emirinin Bizans İmparatoru tarafından gönderilen elçileri nasıl karşıladığına ve onları karşılamak için nasıl bir heyet gönderdiğine dair bilgi olmamasına rağmen gönderilen heyet ile ilgili bir takım bilgiler bulunmaktadır. Bizans elçilik heyeti saray tercümanı Kratius başkanlığında gelmiş ve II. Abdurrahman'ın huzuruna çıkıp ona İmparatordan hediye sunmușlardır. II.Abdurrahman bu hediyeleri kabul etmiş ve bunların karşılığında kendisi de İmparatora hediye göndermiştir. ${ }^{54}$ Aynı zamanda Bizans İmparatoruna Yahya el-Gazzal ${ }^{55}$ adlı tercümanlardan bir elçi olarak gönderilmiştir. Yahya el-Gazzal gelen heyetle birlikte Bizans'a gitmiştir. ${ }^{56}$

Yahya el-Gazzal, Yahya adındaki diğer bir kişi ile birlikte Bizans heyeti ile Endülüs başkenti Kurtuba'dan yola çıkarak Doğu'ya doğru Güney Akdeniz üzerinden Konstantinopolis'e gitmiştir. ${ }^{57}$ Çağdaş Fransız Oryantalist Evariste Lévi Provençal Bizans

\footnotetext{
${ }^{50}$ Ali b. Hasen El-Mesudî,, Muruc El-Zehab ve Maadin El-Cevher, C,III, Thk,: Muhammed Abdulmecit, Daru'1-Fikir Yay., Beyrut, 2005, s. 473: Takûş, age, s. 150: K.U. Zettersteen,agm., s.748-749; Vasiliev, age, s.320.

${ }_{52}^{51}$ Vasiliev, age, s.321.

52 Abdulrahman b. Muhammed İbn-i Haldûn, El-ibar ve divan El-mübtede ve El-haber, C.IIIV, Müasese Cemal Yay., Beyrut, 1979, , s.282.

${ }^{53}$ Şihab El-din Ahmed b. Muhammad Mükrî, Nefh El-Tîb min Gunus El-Edülüs El-Ratîb, C.I.,Thk: Muhammed Abdulhamid, Seadet Matbaasi Yay., Kahire 1949, s. 347.

${ }^{54}$ İbn-i Haldûn, age, s. 282.

${ }^{55}$ Yahya el-Gazzal dış görünüş olarak güzel, hazırcevap, bilgelik ve şiir yönünden becerikliydi. Bütün bu özellikleri Bizans Sarayında karşılaştığı her durumda tecelli etmiştir. Ancak kaynaklar onun bu görevdeki diplomatik görevleri ve siyasi tecrübelerini zikretmemişlerdir. Onun hakkında tek bildiğimiz, heyetin veya elçinin hedefleri hakkında konuşurken ele alacağımız, Bizans İmparatoru'nun taleplerini madde madde takip eden Emevi Emirinin mektubunu teslim etmesidir. Bkz. İbn-Said El Mağribî, El-Mă̆rip fi Hüley El-Mağrip, C.II, Kahire, 1955, s. 58.

${ }^{56}$ Mükrî, age, s.282.

${ }^{57}$ Ömer b. Hasen İbn-Dihiyye, El-Mutrab min Eşâr Ehil-Mağrib, Thk.:İbrahim Elibari, Daru'l-ilim Yay., Beyrut, 1998, s. 139.
} 
heyetinin görevlendirilmesi ve onlara karş1lı görevlendirilen Yahya el-Gazzal'ın ne amaçla Bizans'a elçi olarak gönderildiğine dair bir bilgiyi 19. yy'ın ilk yarısında İbn Hayyan'ın II.Abdurrahman emirliği dönemindeki Endülüs tarihi ile ilgili kitabından bir bölümü alıntılayarak bize aktarmıştır. İbn Hayyan da bu olayı H. 14. yy'da yaşamış olan Muhammed b. Ferec ve İsa b. Ahmed er-Razi ${ }^{58}$ adındaki iki Endülüs'lü tarihçiden rivayet etmiştir. ${ }^{59} \mathrm{Bu}$ iki tarihçinin telif ettikleri tarih kitaplarının aslı bizlere ulaşmamış, yalnızca modern tarihçilerden bizlere o kitaplardan dağınık bir şekilde alıntılar ulaşmıştır. ${ }^{60}$ Garip olan şu ki Lévi Provençal'ın İbn Hayyan'ın tarihinden alıntılayıp ortaya attığı kısmın haricindeki kısımlar Provençal'ın ölümünden sonra kaybolmuş ve bu güne kadar ardından bıraktığı çalışmalarından da bu konuya dair bilgiye rastlanmamıştır. Modern tarihçilerin Lévi Provençal tarafindan yayınlanan ya da yazılanlara güvenmekten başka seçeneği yoktur. ${ }^{61}$

Dolayısıyla günümüz kaynakları Bizanslılar'la diplomatik ilişkiler konusunda görevlendirilen heyetleri basit bir şekilde ele almaktan öteye geçmemiştir. Modern araştırmacıların bildirdiği gibi bu heyetlerin görevlendirmelerindeki amaç ve hedeflerinden çıkarılacak sonuçlarla ilgili farklı görüş ve açıklamalara rağmen basit anlatımlardan öteye geçilememiştir.

Heyetin hedefleri ile ilgili İbn Hayyan'dan rivayet edilene göre; Bizans elçisi Kratius'un İmparator Theophilos'tan Emir II. Abdurrahman'a iletilmek üzere getirdiği mektupta şu istekler bulunmuştur:

1- Endülüs Emevi-Doğu Roma İmparatorluğu tarafları arasında bir mutabakat ve iletişim muhtırası oluş̧urma ve aralarında elçilik heyetleri ile bağlantı kurma,

2- Emevi emirinin doğudaki atalarının mülküne sahip çıkması, imparatorun bu konuda ona yardımcı olacağı,

3- Girit Adası'nın Doğu Roma'ya geri verilmesi ve orayı fetheden Arapların sınır dışı edilmesi,

4- İki devlet arasında bir dostluk anlaşması yapılması. ${ }^{62}$

Endülüs emirinin Yahya el-Gazzal ve yol arkadaşı ile birlikte Doğu Roma İmparatoru'na gönderdiği mektupta bu isteklere madde madde cevap yazılmıştır. Emir'in imparatora gönderdiği mektupta ise II. Abdurrahman, İmparatorun mektubunun kendisine ulaşttğııı söyledikten sonra geçmişte İmparatorun dedeleri ile Şam'daki Emevi Devleti arasındaki dostluk duygularını ve bu duygunun pekişme isteğini anlayışla kabul etmiş̧tir. Bu nedenle İmparatorla görüşmesi için bir elçi gönderdiğini ve bu duyguyu pekiştirmek ve bir güvence olmak üzere İmparatorun onu kabul etmesi ve onu güzel bir şekilde ağırlamasını istemiştir. Bundan sonra Emir II.Abdurrahman ilişkilerin yenilenmesine ve bu ilişkilere bağlı olmaya istekli olduğunu açıklamıştır. Sonra Emir, İmparator Theophilos'un mektubunda dile getirdiği Emevi Devleti'nin son halifesi Mervan b. Muhammed'in ${ }^{63}$ Abbasilerle yaptığ 1 savaşlar

\footnotetext{
58 İsa b. Ahmed er-Razi, Endülüslü bir tarihçi olup H. 4. yy'da yaşamıştır, ailesiyle birlikte tarih ile uğraştıkları bilinir fakat telif ettiği kitapların birçoğu günümüze kadar gelememiştir. Bu kitaplar arasında "El-hacib Lilhulefâ bi endülüs” de bulunmaktadır. İbnül Ebâr, Muhammed b. Abdullah, El-Hulletü'lSiyerâ, C.II, Thk.: Hüseyin Mü'nes, El-Şirke El-Arabiye Yay., Kahire, 1963, s. 138.

${ }^{59}$ Lévi Provençal, Tarihu'l-İslam fi Mağrip ve Endülüs, Nahda Mısır Yay., Kahire, 1965, s. 99-97.

${ }^{60}$ Hayyan b. Halef İbn- Hayyan, El-Muktebes min Ahber Beledu'l-Endülüs, Thk.: Salehettin Havarî, Mektebatu'lAsriyye Yay., Beyrut, 2006, s.118-119.

${ }^{61}$ Suleyman Rahilî, Sefarat İslamiyye, Mekteba Tübe Yay., Riyad, 1990, s. 142.

${ }^{62}$ Provençal, age, s. 99-97.

${ }^{63}$ Mervan b. Muhammed Şam merkezli Emevi Devleti'nin son halifesidir. Savaşlarda çok sabırlı olduğu için ona Eşek lakabı verilmiştir. Emevi tahtına çıktığında Abbasi devrimi son aşamasına gelmişti. O Abbasi hareketine karşı direniş göstermesine rağmen H.132 yılında Musul yakınlarında bir yerde Abbasilere karşı yenik düşmüş ve daha
}

\section{History Studies}


neticesinde öldürülmesi ve bu olaylarla ilgili şahsi değerlendirmelerini dile getirmiştir. Doğu Roma İmparatoru'nun Abbasi Halifeleri Me'mun ve Mu'tasım'a değindiği konu ile ilgili ise ikisinin davranışlarının hatalı olduğunu ve yönetilenlere yönelik ağır siyasetle muamele ettiklerini dile getirmiştir. Devletlerinin sona ermesi ve halifeliğin Endülüs Emevi Hanedanlığına geçmesinin pek uzak olmadığını, böylece Emevilerin onlara yardımc1 olacaklarını ve doğudaki mülkiyetlerine döneceklerini belirtmiştir. Bu durumda Doğu'ya vurgu yapan Emir, Şam ve Endülüs'teki güvenliği de Doğu Roma'ya bıraktığını ifade etmiştir. Girit'te bulunan, Bizans donanmaları ve civar adalara hücum eden Araplara karşı Endülüs Emevilerinin kendilerine yardım etmeleri ile ilgili ise bunların zaten Endülüs Emevi Devleti'ne karşı geldiklerini ve aralarında hiçbir ilişki ve bağ bulunmadığını ifade ederek bunların artık Abbasi Halifesi'ne bağlı bulunduklarını söyleyerek bunların yaptıkları karşısında imparatoru anladığını belirtmiş, Emevilerin doğuya döndüklerinde ve Abbasi hakimiyetine son verdiklerinde bu durumla ilgilenebileceğini söylemiştir. ${ }^{64}$

Emevi Emirinin yazdırdığı mektubun akışından anlaşıldığına göre her iki devlet arasındaki bazı durumlar Bizans İmparatoruna gönderilecek mektupta ele alınmamış Bizans elçisine şifahen açıklama yapılmıştır. Bu durumların da İmparatora gönderilecek elçilerle ilgili açıklamalardan müteşekkil olduğu ihtimal dâhilindedir. Bunu Emirin İmparatora hitaben yazdığı mektubun son paragrafinda yazılan şu metinden anlamaktayız:

"Elçin Kratius'u huzurumuza aldık. Bize tembih ettiğin durumları ve dostun dostuna bildirmesi gereken durumlarla ilgili açıklamalarını anladık, sana yazdı̆̆ımız bir mektubu tarafımızdan iki faziletli elçimizle sana gönderdik. Bize yazmış olduğunuz durumlarla ilgili ne istediğinizi ayrıca esenliğiniz ve sağlam bir hayat için size ne gerektiği ile ilgili bize bir mektup yazın ki sizden gelene karşılık nereye yöneleceğimize bakalım." 65

Aralarında politik heyetlerin gidip geldiği Endülüs Emevi ve Bizans devletlerinin siyasi durumlarını araştırdığımız zaman bu iletişimin amaçları ve her bir tarafın kendi tarafından isteklerine 1şık tutacak birkaç bilgi bulunabilmektedir. Bu amaç ve sonuçların incelenmesi sonucunda her bir tarafın diğeri ile ilişkiden neleri elde ettikleri ortaya çıkmıştır.

Görüldüğ̈̈ üzere bu heyet Abbasilerin Bizans'ın güney sınırlarına baskılarının arttığı zamanda Endülüs Emevi Devleti'ne gelmiştir. Zira özellikle bu saldırılar Halife Mu'tasım döneminde doruğa ulaşmış ve 838 yılında Halife Mu'tasım Amûriye cephesinde Bizans'a karşılık yapılan baskına bizzat kendisi de katılmıştır. ${ }^{66}$ İmparator Theophilos korkunç bir şekilde yenilgiye uğramış ve bu yenilgi, İmparatorluğun hakim olduğu bölgede dehşet ve korku etkisi yaratmıştır. Bunun üzerine İmparator Theophilos hem Hıristiyan milletlere yardım çağrısında bulunmuş hem de Endülüs Emevilerine elçi göndermek suretiyle onları Abbasilere karşı kışkırtmak ve bu suretle bir düşmanını bir başka düşmanı aracılı̆̆ıyla yok etmek istemiştir. Diğer yandan İmparator Theofilos, M.839 yılında elçilerini Frank Kralı I. Ludwig'e (814-840) gönderip kontrolü altında bulunan yerleri Abbasilere karşı korumalarını ve kendisine bu konuda destek vermeleri için yardım talebinde bulunmuştur. ${ }^{67}$

İmparator Theofilos'un Abbasilere karşı müttefik bulma konusundaki girişimleri içinde bulunduğu durumun oldukça zor olduğunu ispat etmektedir. İmparator, Endülüs Emevi Emiri II. Abdurrahman'a gönderdiği mektupta Endülüs Emevilerini kendi tarafına yönlendirme ve

sonra Mısır'da öldürülmüştür. Bkz; Muhammed b. Ahmed Dahabî, Seyr Alem El-Nubala, C. IIIV, Thk.: Hassan Abdulmenan, El-Risale Yay, Beyrut, 1996, s.76.

${ }^{64}$ Mektubun ayrıntıları için Bkz; Provençal, age, s. 114-118.

${ }^{65}$ Provençal,age, s. 118.

${ }^{66}$ El-Tabarî, age, s. 57-79.

${ }^{67}$ Rahilî, age, s. 145-146. 
Abbasilere karşı onlarla bir anlaşma imzalamaya teşebbüs etmiş ve bunu yapabilmek için de bazı taktiklere başvurmuştur. Bunlardan birincisi Emevi Emirine geçmişte atalarının Şam'da Bizanslılarla ilişkisini hatırlatarak dostluk bağı kurmaya çalışması olmuştur. $\mathrm{Bu}$ yolla İmparator asıl ve gerçek olan amaç ve isteklerinin üstünü mübalağa ve iltifatlarla kapatarak bir şeyleri anlatmaya çalışmıştır. Nitekim bu da asırlardır tekrar edilen Bizans politikalarının alışılagelmiş diplomatik manevralarıdır. İmparator Theofilos'un işaret ettiği sadakatin aslı, Şam Emevi Devleti döneminde Konstantinopolis'in kendisini bile tehdit edecek dereceye ulaşmış ve Arapların yaptığı akınların Bizans'a yaşattığı zorluklar sonucu ile yapılan anlaşmalardır. ${ }^{68}$ İkincisi ise Endülüs Emevilerini harekete geçirip doğuda egemen olan Abbasilere karşı onları kışkırtmak olmuştur. Ancak Emevi-Abbasi düşmanlığ İmparatorun hayalini kurduğu şekilde iki Müslüman devletin yani Endülüs Emevilerinin Abbasilere karş1 Hıristiyanlarla birlik olup onlara yardım edip, kollayacağ 1 kadar büyümemiştir. Zira bu Abbasi veya Endülüs Emevi halifelerinin veya emirlerinin itibar edilecekleri bir durum olmamıştır. ${ }^{69}$ Dolayısıyla Endülüs Emevileri, Abbasilere karşı Doğu Romalılar ile yapılacak olan herhangi bir anlaşmaya girişmemişlerdir. Her ne kadar İmparator Abbasileri düşürmek için Endülüs Emevileri'ni kendi yanına çekme çabalarına başvurmuş olsa da hiçbir zaman hedefine ulaşamamıştır. Zira Abbasiler de son 70 yıl Endülüs Emevilerini ele geçirme denemelerinden bile vazgeçmiş, Doğu sınırlarıyla meşgul olmuş, hatta Endülüs'ten daha yakın bölgelerde bile bu tür hareketlere teşebbüs etmemiştir. Örneğin İdrisilerin ${ }^{70}$ ele geçirdiği Fas'ın dahi Harun Reşid'in halifeliğinden beri geri alınmaya çalışılması gibi bir harekete girişilmemiştir. ${ }^{71}$ Diğer yandan o zamanlar Endülüs Emevi Devleti'nin karşı karşıya olduğu tehlike Abbasiler değildi. Zira onlar için en yakın ve en büyük tehlike Endülüs'ün kuzey komşusu olan Hıristiyan krallıklardı. Ayrıca Fas'ta bulunan İdrisiler ve Fatımiler tehlikesi varken Endülüs Emevilerinin Bizans İmparatorunun isteğiyle kendilerini sonu belli olmayan bir yola sürüklemeleri söz konusu bile olmamıştır. Ayrıca Endülüs Emevileri kendi iç işleri ile ilgilenmekteydiler çünkü devlet içindeki fitne ve ayaklanmalar güçlerini kendilerine epey uzak olan doğu taraflarından ziyade kendi iç işlerine yönlendirmek zorundaydı. ${ }^{72}$

Emevi Emiri, İmparatorun Girit yarımadasındaki Endülüslü Müslümanların Bizans'a yönelik tehlikelerine karşı yardım isteğine karşılık da herhangi olumlu bir cevap veya tutum belirtmemiştir. Nitekim Emir, mektubunda İmparatora bunların Endülüs Emevi Devletine tabi olmadıklarını, bölgelerinin uzak olduğunu ve bağlı bulundukları devletin değiştiğini vurgulamıştır. Bizans İmparatorunun bunların genç güçleri karşısında ve elim baskınlarına karş1 aciz oluşunu beyan etmesine rağmen bu durumun itaatleri altında bulundukları Abbasilerin özel siyasi bir meselesi olduğunu belirtmiştir. Bütün bunlardan anlaşıldığına göre Bizans İmparatoru, Emevi Emirinden hürmet ve iltifat belirten ibareler ve gelecekle ilgili müphem vaatler dışında elle tutulur bir şey elde edememiştir. Dolayısıyla Jamil Nahla, Salahattin el-Müncit ve diğer bazı modern araştırmacıların dile getirdikleri, Emevilerin Bizans'la Abbasilere karşı anlaşma yaptığı düşüncesi, her iki devlet arasında bu dönemde gidip gelen elçilik heyetlerine bağlanarak ortaya atılmıştır. Gerçek şu ki bu durum Bizans'ın hedeflediği ve Emevilerin önem vermediği bir durumdur. Diğer yandan böyle bir anlaşma tarih sahnesinde vuku bulduğuna dair bilgisi olmayan ve bilimsel metodlar çerçevesinde

\footnotetext{
${ }^{68}$ El-Tabarî, age, s. 530,531.

${ }^{69}$ Abdurrahman b. Muhammed İbn-i Haldûn, Mükadima İbn-i Haldûn, C.I, Daru'l Avda Yay., Beyrut 1981, s.180; Rahilî, age, s. 147.

${ }^{70}$ İdrisiler, İdrise b. Abdullah b. Hasen b. Ali b. Ebî Talib'ın soyuna bağlı kişiler olup H. 172-363 yılları arasında Fas'ta bir devlet kurarak hüküm sürmüşlerdir. Ancak daha sonra Endülüs Emevileri tarafından yıkılmışlardır. Daha geniş bilgi için Bkz: Abbas Nasru'llah Sadûn, Edarise El-Mağrib , Daru'l-Nahda El-Arabiyye,Kahire 1987, s.5.

${ }^{71}$ Sadûn Abbas, age, s.6.

${ }^{72}$ Provençal, age, s.94.
} 
ispatlanamayan bir iddiadan ibarettir. ${ }^{73}$ Eğer böyle bir anlaşma gerçekte var olmuş olsaydı bu anlaşmayı güvence altında tutmak, kayıt altına almak ve kalıcılığını gerçekleştirmek için sık sık elçilik heyetlerinin gidip gelmesi gerekirdi. Nitekim hem İmparator Theofilos hem de II. Abdurrahman döneminden sonra yaklaşık bir yüzyıl boyunca diplomatik kesinti yaşanmış ve Endülüs Emevi Devleti'nin Emirlikten Halifelik dönemine geçişinden sonra iki taraf arasındaki ilişkilerde yeni bir dönem başlamıştır. ${ }^{74}$

Runciman, Abdulaziz Salim, Pirenne, İbrahim el-Advi ve birçok araştırmacı Bizans-Endülüs Emevi ilişkileri ile ilgili farklı bir görüş etrafında toplanmışlardır. Onlara göre; Endülüs EmeviBizans ilişkisi, Galya bölgesinde yapılan Abbasi ve Frank Krallığı arasındaki diplomatik ilişkilere cevaben girişilmiş bir ilişkidir. Yani Abbasi-Frank Krallı̆̆ı ilişkilerine karşı Bizans'ın Endülüs Emevileri ile ittifak kurduğunu Emevilerin de aynı şekilde Abbasiler ve Frank Krallığına karşılık vermek için bu anlaşmayı yaptıklarını savunmuşlardır. ${ }^{75}$ Ancak bu görüş de açık tarihi kanıtlara ihtiyaç duymaktadır. Zira Bizans-Emevi ilişkisinde bu fikri veya yönelimi savunacak her hangi bir değer bulunmamıştır. Nitekim Emevi Devletine yönelik tehlikeler arasında Frank Krallığı tehlikesi olmadığı için Emevi Devleti'nin bu tehlikeyi hafifletmek amacıyla Bizans'a sığınması söz konusu değildi. Bilakis Emevi ve Frank Krallığı arasındaki ilişkiler, Bizans'la ilişkiler başlayınca daha da yumuşamıştır. ${ }^{76}$ Çünkü Frank Krallığı güçsüzleşmeye ve gerilemeye başlamış, güneydeki komşusu olan Emevilere yönelik tehlikesi de ciddiyetini kaybetmiştir. Diğer bir yandan Bizans ve Franklar Hıristiyan iken Abbasi ve Emeviler anayasaları bir olan bir dine mensupturlar ki anayasalarının en önemli maddelerinden biri de Müslümanlara karşı Daru'l-Harb ehli ve destekçilerine yardım etmenin caiz olmayışıdır. Aralarındaki düşmanlık ne kadar büyük olsa da bu caiz olmama durumunda bir değişiklik söz konusu olmamıştır. ${ }^{77}$

Bazı araştırmacılar da Yahya el-Gazzal'ın Konstantinopolis'e gitmediğine, Kuzeydeki Danimarka Kralına gittiğine dair bir görüş ileri sürmüşlerdir. Bu görüşlerini de bu konuyu elMutrib kitabında ayrıntılı bir şekilde ele alan İbn Dahiyye' nin $^{78}$ rivayetine dayandırmışlardır. Bu kitapta Yahya el-Gazzal'ın Konstantinopolis sarayına gittiğine dair çıktığı bu yolculukla ilgili hiçbir bilginin bulunmadığını söylemişlerdir. Hâlbuki ibn Dahiyye'den önce yaşamış İbn Hayyan, İbn Haldûn, el-Makri gibi birçok tarihçi el-Gazzal'ın iki yolculuğundan birinin Bizans'a diğerinin kuzeydeki Danimarka'ya olduğunu bildirmiş̧ir. Dolayısıyla bu tartışmayı gerektirmeyen bir konudur. ${ }^{79}$

İbn Hayyan, İbn Haldun ve el-Makri gibi müelliflerin kaynaklarında geçen Yahya elGazzal'ın Bizans'a yolculuğunun M.839 yılında Bizans'ın Kurtuba'ya elçi gönderdikten hemen sonra, aynı yılda olduğu kaydedilmiştir. Bununla birlikte İbn-Dahiyye'nin ayrıntılı bir şekilde

\footnotetext{
${ }^{73}$ Cemil Nahla El-Mudevver, Hadaratu'l-İslam fi Daru'l-Selam, Bulak Matbaa Yay., Kahire, 1936, s.211; Salahettin Müncit, Fusul fi el-Diplumasiye, Lecne El-Talif Yay., Kahire 1947, s.158-159.

${ }^{74}$ Rahilî, age, s. 154.

${ }^{75}$ Runciman Steven, "Charlemange and palistine", The English Historical Review, Volume L, Issue CC, 1 October 1935, P, s. 606-619.; El-Mudevver, age, s.211-213.; Henri Pirenne, Muhammed and Charlemage, Unwin Broters LTD Yay., London, 1974, P,160; Abdulaziz Salim, Diraset fi tarih El-Arap, C. III, Muasese Şebab Yay,. İskenderiye, 1998, s.242-244; İbrahim El-Advî, El-Sefaret El-İslamiye Avrupa fi Usur el-Vasta, Daru'l-Maarif Yay., İskenderiye, 1957, s. 100.

${ }^{76}$ Franklar ile Emeviler arasındaki ilişkiler hakkında daha geniş bilgi için Bkz. Muhammed Mursi, Devletu'l-Firince ve alakatihe Bil-Emeviyin fi Endülüs, El-Sekafetu'l-Cemieyye Yay,. İskenderiye, 1981, s.215-290.

${ }^{77}$ Abbasiler ile Franklar arasında ilişkiler hakkında daha geniş bilgi için bkz. Suleyman El-Rahili, El-İlakat ElSilmiye Beyin Devletu'l-Abbasiye ve Avrupa fi Asir Abbasi El-Mübekir, (Muhammed b. Suud Üniversitesi,Tarih Bölümü Yayınlanmamış Yüksek Lisans Tezi), Riyad, 1981, s. 95-133.

${ }^{78}$ El-Rahilî, Age, s. 139-144.

${ }^{79}$ El-Rahilî, Sefarat İslamiyye..., s.151-152.
} 
ele aldığı Yahya el-Gazzal'ın Normanların memleketine yolculuğu M.844 yılının sonlarına denk gelmiştir. Yani Normanların Endülüs'e baskınlarının son bulduğu yıl bu yolculuk gerçekleşmiştir. $^{80}$

$\mathrm{Bu}$ şekilde iki yolculuk arasındaki zaman farkı yaklaşık beş seneye tekabül etmiştir. $\mathrm{Bu}$ sürenin Konstantinopolis ve Normanlar Krallığ Özellikle bazı kaynaklar yolculuğun dokuz ay sürdüğünü göstermiştir. Bu nedenle akla, Yahya el-Gazzal'ın Konstantinopolis'e gelip burada üç yıl veya daha fazla kaldığı daha sonra kuzeydeki Norman Kralına yeni bir görev için sefer yapmak üzere seçildiği gelmektedir. İkinci sefer elçi olarak seçilmesinin nedeni de ilk görevde elde ettiği tecrübeler olmuştur. ${ }^{81}$

Genel olarak bu konuda üç farklı görüş ileri sürülmüştür:

1- Bir grup, Yahya el-Gazzal'ın iki görev için yolculuğa çıktığını, birinci yolculuğunu doğuda bulunan Bizans'a ikincisini kuzeyde bulunan Danimarka'ya yaptığını savunmuştur. Bunlardan bazıları bu iki seferin birbiriyle ilişkili olduğunu söylemiştir. Tarihçilerin çoğu bu birinci görüşü savunmuştur. Nitekim Vasilyev, Huseyn Mu'nis, Şakir Mustafa ve Edwin Hall bu görüşü savunan tarihçilerdendir. ${ }^{82}$

2- Diğer bir grup, Yahya el-Gazzal'ın yalnızca Bizans'a yönelik gerçekleştirdiği yolculuğun doğru olduğunu diğer yolculuğun vaki olmadığını savunmuştur. $\mathrm{Bu}$ görüşü savunanların en meşhuru Fransız Oryantalist Lévi Provençal'dır. ${ }^{83}$

3- Üçüncü grup ise, Yahya el-Gazzal'ın yolculuğunun kuzey tarafta bulunan Danimarka'ya yönelik olduğunu söylemiş, bu yolculukla ayrıntılı bir şekilde ilgilenmiş ve Yahya el-Gazzal'ın Konstantinopolis'e yaptığı yolculuğu hiç ele almamıştır. İbrahim el-Adevi bu görüşü savunmuştur. ${ }^{84}$

Birinci görüş, tarihi kaynaklar ve Yahya el-Gazzal'ın yolculuklarının sırasıyla okunmasına uygunluğu açısından diğerlerinden daha çok kabul gören görüş olmuştur. Nitekim bu elçilerin görevlendirilmesindeki amaçların incelenmesi olan bu çalışmamızda da açıkça görülmüştür.

\section{SONUÇ}

Doğu Roma İmparatorluğu İslamiyetin ortaya çıkışından sonra Müslüman Arapların yoğun bir tehdidine maruz kalmıştır. Hz. Muhammed(S.A.V.) döneminden itibaren başlayan bu tehdit Dört Halife döneminde daha da artmıştır. Hz. Ali dönemindeki iç karışıklıklar döneminde Doğu Roma açısından biraz rahatlama söz konusu olsa da Emevi Devleti'nin kurulmasından sonra bu tehditler daha da artmıştır. Nitekim Emeviler döneminde Müslüman Araplar Doğu Roma başkenti üç kez kuşatma girişiminde bulunmuştur.

Emevilerden sonra İslam dünyasının siyasi hakimiyetini ele geçiren Abbasiler döneminde de Doğu Roma İmparatorluğu'nun doğu sınırlarındaki tehdit devam etmiştir. Abbasi Halifesi Harun Reşid döneminde en güçlü bir hal alan bu tehdit nedeniyle halifeye barış teklif eden İmparatoriçe İrene yılda iki kez olmak üzere 70.000 dinar vergi vermeyi dahi kabul etmek zorunda kalmıştır. Harun Reşid'in ölümünden sonra Abbasi Devleti içinde başlayan iç mücadeleler nedeniyle Doğu Roma İmparatorluğu bir süreliğine doğu sınırlarında rahat nefes almaya başlamıştır. Ancak onun oğlu Me'mun'un siyasi birliği sağlamasından sonra yeniden

\footnotetext{
${ }^{80}$ El-Rahilî, Age, s. 152 .

${ }^{81}$ Hüseyn Mü'nis, “Garatu'l-Nurman ale-Endülüs”, Mısır Tarih Dergisi, C,II., S.I., 1949, s.42-52.

${ }^{82}$ Mü'nis, age, s.44-45.

${ }^{83}$ Provençal, age, s.113-114.

${ }^{84}$ El-Advî, age, s. 112-116.
} 
güçlenmeye başlayan Abbasiler, Doğu Roma İmparatorluğu için tehdit olmaya devam etmiştir. Halife Me'mun ile çağdaş olan Doğu Roma İmparatoru Theofilos ise bir yandan Abbasilere karşı düşman politikalar üretirken ve saldırıya geçmek için askeri hareketlere girişirken bir yandan sosyo-kültürel, dini anlamda Abbasilerden etkilenmekten kendini alıkoyamamıştır. Nitekim Abbasi tehdidini bertaraf etmek için Babek El-Harami isyanına destek veren İmparator Theofilos, diğer yandan da Abbasi saraylarından etkilenerek İstanbul'da Bryas sarayını yaptırmış, Harun Reşid gibi tebdil-i kıyafetle halk arasında dolaşmıştır. Ülkesinde uzun zamandır tartışması bile yapılmayan tasvir kırıcılık yanlısı tutumu yeniden sergilemesi İslam dininin uygulamalarından esinlediğini net bir şekilde düşündürmektedir. Yine Halife Me'mun'a bazı eski Yunanca yazma eserleri göndererek onunla kültürel bir alış verişte bulunması onun Halife'ye ve İslam dünyasına gösterdiği sempatiyi ispat etmektedir.

İmparator Theofilos tüm bunların yanında bir devlet adamı olmanın gereği olarak ülkesini tehditlere karşı korumak için çeşitli tedbirler almayı da ihmal etmemiştir. Halife Mutasım Billah döneminde Doğu Roma'nın en korunaklı kalelerinden biri olan Amûriye'nin tehdit edilmesi üzerine kaleyi korumak için harekete geçmiş ancak başarı sağlayamamıştır. Bunun için Doğu Roma'nın öteden beri uygulamış olduğu ve özellikle Avrupa'da da kısmen başarılı olduğu bir düşmanını bir başka düşmanına kırdırmak gibi bir politikaya başvurarak Endülüs Emevi Emiri II. Abdurrrahman'a bir elçilik heyeti göndermiş, aralarındaki ayrılıktan yararlanmak amacıyla onları Abbasilere karşı kışkırtmak istemiştir. Ancak Endülüs Emevi Devleti ve Abbasilerin o günkü islam dünyasındaki Şiî hareketler karşısında Sunnî İslam noktasındaki birlikteliği böyle bir ittifakı engellemiştir. Diğer yandan aralarında siyasi ayrılık söz konusu olsa da Müslüman bir devletin yani Endülüs Emevilerinin Abbasilere karşı Hıristiyanlarla birlik olup onlara yardım etmesi gibi bir ihtimal çok zayıf görünmektedir. Zira Endülüs Emevi Devleti'nin kuzeydeki Hıristiyan krallıklar, Fas'ta İdrisiler ve Fatımiler gibi büyük tehlikeler ile uğraşmak yerine Abbasilere karşı bir ittifak içinde yer alması da mümkün değildir. Dolayısıyla Endülüs Emevileri, Abbasilere karşı Doğu Romalılar ile yapılacak olan herhangi bir anlaşmaya girişmemiş̧ir. İmparatorun da Abbasilere karşı Endülüs Emevileri'ni kendi yanına çekme çabaları hiçbir zaman hedefine ulaşamamıştır.

Sonuç itibariyle Doğu Roma İmparatorluğu İmparator Theofilos döneminde de uygulanan tüm politikalara rağmen doğudaki İslam tehdidinden kurtulmayı başaramamıştır. Ancak bununla birlikte İmparator Theofilos İslam dünyası ile sınırlarını korumak için tavizsiz bir şekilde mücadele etmiş, diğer yandan da İslam dünyasındaki bir takım bilimsel, sanatsal ve kültürel faaliyetleri takip etmiştir.

\section{KAYNAKÇA \\ KITAPLAR}

APAK, Adem, Ana Hatlartyla İslâm Tarihi(Hz. Muhammed(s.a.v) Dönemi), C.I-IV., Temel Kültür Dizisi Yay., İstanbul, 2015.

AVCI, Casim, İslâm-Bizans İlişkileri(610-847), Türk Tarih Kurumu Yay., Ankara, 2015.

DAHABÎ, Muhammed b. Ahmed, Seyr Alem El-Nubala,Thk, Hassan Abdulmenan, C.IIIV, ElRisale Yay, Beyrut,1996.

EL-ADVÎ, İbrahim, El-Sefaret El-İslamiye Avrupa fi Usur el-Vasta, Daru'l-Maarif Yay., İskenderiye, 1957.

El-Endülüs Vemafiha min Bilad, Thk, D. Halil el-Cubûrî, Daru'l-Kitap El-Alemiyye, Tekrit, 1971. 
El-MESUDÎ, Ali b. Hasen, Muruc El-Zehab ve Maadin El-Cevher, C,III, (Thk, Muhammed Abdulmecit), Daru'l-Fikir Yay., Beyrut, 2005.

El-MUDEVVER, Cemil Nahla, Hadaratu'l-İslam fi Daru'l-Selam, Bulak Matbaa Yay., Kahire,1936.

EL-TABARÎ, Muhammed b. Cerir, Terih El-Russul ve El-Mulûk, C.IX, Thk, Muhammed İbrahim, Daru'l-Maarif Yay., Kahire,1967.

HAMAVÎ, Yakut, Şıhabüddin Abdullah Yakut b. Abdullah, Muacem El-Buldan, , Darü’s Sadr Yay., Beyrut, 1977.

İBN-DİHIYYE, Ömer b. Hasen, El-Mutrab min Eşâr Ehil-Mağrib, (Thk, İbrahim El-İbari), Daru'l-ilim Yay., Beyrut, 1998.

İBNÜ'L EBÂR, Muhammed b. Abdulllah, el-Hulletü'lSiyerâ, C.II, (Thk, Hüseyin Mü'nes), ElŞirke El-Arabiye Yay., Kahire,1963.

İBN-ESİR, Ali b. Muhammed,El-Kâmil fil-tarih,(Thk,Abdullah El-Kadî), Daru'l-Kutup Yay., Kahire, 1987.

İBN-İ HALDÛN, Abdulrahman b. Muhammed, El-ibar ve Divan El-mübtede ve El-Haber, C.IIIV, Müasese Cemal Yay., Beyrut, 1979.

İBN-İ HALDÛN,Mükadima İbn-i Haldûn, Daru'l Avda Yay., C. I, Beyrut 1981.

HISTORY

İBN- HAYYAN, Hayyan b. Halef, El-Muktebes min Ahber Beledu'l-Endülüs, (Thk, Salehettin Havarî), Mektebatu'l-Asriyye Yay., Beyrut, 2006.

İBN-SAİD El-Mağribî, El-Mağrip fi Hüley El-Mağrip, C. II, Kahire, 1955.

KERİM , Muhammed Salim, El-Şuubiyye Neşeteha ve Tetavvuruha, Daru'l-Cumhuriye Yay., Misrata, 2004.

MÜKRÎ, Şihab El-Din Ahmed b. Muhammad, Nefh El-Tîb min Gunus El-Edülüs El-Ratîb, C.I, (Thk, Muhammed Abdulhamid), Seadet Matbaası Yay., Kahire, 1949.

MÜNCİT, Salahettin, Fusul fi El-Diplomasiye, Lecne El-Talif Yay., Kahire, 1947.

MÜ'NİS, Hüseyn, “Garatu'l-Nurman ale-Endülüs”, Misır Tarih Dergisi, C,II, S.I, Kahire, 1949.

MURSİ, Muhammed, Devletu'l-Firince ve Alakatihe Bil-Emeviyin fi Endülüs, El-Sekafetu'lCemieyye Yay,. İskenderiye, 1981.

PIRENNE, Henri, Muhammed and Charlemage, Unwin Broters LTD Yay,. London, 1974.

PROVENÇAL Levi, Tarihu'l-İslam fi Mağrip ve Endülüs, Nahda Mısır Yay,.Kahire, 1965.

RAHILÎ, Suleyman, El-İlakat El-Silmiye Beyin Devletu'l-Abbasiye ve Avrupa fi Asir Abbasi El-Mübekir,( Yayınlanmamış Yüksek Lisans Tezi), Muhammed b. Suud Üniversitesi,Tarih Bölümü, Riyad,1981.

RAHILLI, Suleyman, Sefarat İslamiyye, Mekteba Tübe Yay., Riyad, 1990.

SADÛN, Abbas Nasru'llah, Edarise El-Mağrib, Daru'l-Nahda El-Arabiyye, Kahire, 1987.

SALIM, Abdulaziz, Diraset fi Tarih El-Arap, C. III., Muasese Şebab Yay, İskenderiye, 1998.

TAKÛŞ, Muhammed Suheyl, Tarih El-Devletu'l-Abbasiyye, Daaru'k-Nefâ's Yay., Beyrut, 2009.

\section{History Studies}


İmparator Theophilos Döneminde (829-842) Doğu Roma İmparatorluğu ile İslam Dünyası Arasındaki İlişkiler

ÜÇOK Bahriye, İslam Tarihi Emeviler-Abbasiler, Milli Eğitim Basımevi Yay., Ankara,1978.

VASILIEV, Alexander A. , Bizans İmparatorluğu Tarihi, Alfa Yay., İstanbul, 2016.

\section{MAKALELER}

AVCI, Casim, “Abbasi Halifesi Me'mun Döneminde Bizans'la İlişkiler”, İSAM, C.IV, S.2, 2011.

BOZKURT, Nahide, “Me’mun”, Diyanet İşleri İslam Ansiklopedisi, C.29, Ankara, 2004.

DARKOT, Besim, "Ammuriye" Milli Eğitim Bakanlığı İslam Ansiklopedisi, C.1, İstanbul, 1970 .

STEVEN, Runciman,"Charlemange and Palistine" The English Historical Review, Volume L, Issue CC, 1 October 1935.

ZETTERSTEEN, K.U., “Mu’tasım”, Milli Eğitim Bakanlığı İslam Ansiklopedisi, C.8, İstanbul, 1970. 